\title{
AAS, growth hormone, and insulin abuse: psychological and neuroendocrine effects
}

\author{
Michael R Graham' \\ Peter Evans ${ }^{2}$ \\ Bruce Davies' \\ Julien S Baker' \\ 'Health and Exercise Science \\ Research Unit, Faculty of Health \\ Sport and Science, University \\ of Glamorgan, Pontypridd, Wales, \\ United Kingdom; ${ }^{2}$ Royal Gwent \\ Hospital, Newport, Gwent, United \\ Kingdom
}

\begin{abstract}
The nontherapeutic use of prescription medicines by individuals involved in sport is increasing. Anabolic-androgenic steroids (AAS) are the most widely abused drug. Much of our knowledge of the psychological and physiological effects of human growth hormone (hGH) and insulin has been learned from deficiency states. As a consequence of the Internet revolution, previously unobtainable and expensive designer drugs, particularly recombinant human growth hormone (rhGH) and insulin, have become freely available at ridiculously discounted prices from countries such as China and are being abused. These drugs have various physiological and psychological effects and medical personnel must become aware that such prescription medicine abuse appears to be used not only for performance and cosmetic reasons, but as a consequence of psychological pre-morbidity.
\end{abstract}

Keywords: AAS, cosmesis, growth hormone, insulin, performance, strength

\section{Introduction}

Athletes, bodybuilders, and recreational weightlifters have been abusing anabolicandrogenic steroids (AAS) since their synthetic production (Ruckzika et al 1935). They are a powerful group of synthetic compounds similar in chemical structure to the natural male steroid hormone testosterone (T) and dihydrotestosterone (DHT) (Haupt and Rovere 1984; Shahidi 2001). They differ from T by the addition of an ethyl, methyl, hydroxyl, or benzyl groups at one or more sites along the synthetic steroid structure (Figure 1).

The risks from chronic administration of AAS may appear relatively low when compared with the use of socially acceptable drugs such as tobacco and alcohol. The literature tends to rely heavily on specific case reports, identifying psychiatric or psychological disorder, because of the private and personal nature of the abuse of this class of drug (Pagonis et al 2006a; Papazisis et al 2007). AAS are taken for their desirable cosmetic effects, to increase size and in the belief that they enhance sporting performance. AAS self-administration has increased over the last decade, in the wake of the demonstration that AAS increase muscle mass and strength in healthy adult males, over and above resistance training (Bhasin et al 1996). The administration of AAS has undesirable effects, which have been extensively reviewed (Haupt and Rovere 1984; Hartgens and Kuipers 2004; Hartgens et al 2004).

However, there may be other reasons why individuals abuse anabolic substances. Thirteen percent of 75 female weightlifters, who admitted to abusing AAS to gain muscle mass, had increased their weightlifting activities to be better able to defend themselves against men and also reported that they were previously sexually abused (Gruber and Pope 1999). It is believed that compulsive weightlifting and AAS abuse may represent a form of response to the trauma of sexual assault and also may assist in raising self-esteem. The psychiatric evaluation of dedicated female athletes also demonstrated the exhibition of ergogenic polysubstance dependence, 


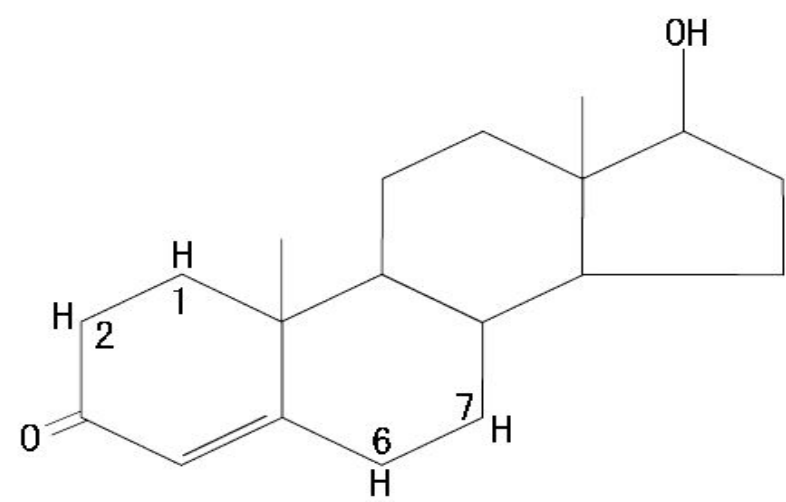

Figure I Testosterone is a steroid hormone from the androgen group. It is the principal male sex hormone and the "original" anabolic steroid.

often with significant co-morbidity (Gruber and Pope 2000). Fifty six percent demonstrated hypomania during the "administration-phase" and 40\% reported depressive symptoms during withdrawal. These athletes also displayed several psychiatric syndromes, previously ill-defined, such as obsessive compulsive disorder (OCD), rigid dietary practice, nontraditional gender roles, and chronic dissatisfaction and preoccupation with their physiques (muscle dysmorphia).

Pagonis and colleagues (2006b) has shown in a study of 160 AAS-abusing athletes compared with 160 placebo and controls that the wide range of psychiatric side effects induced by the abuse of AAS is correlated to the severity of abuse. The force of these side effects intensifies as the abuse escalates.

The latest substances being abused by individuals, associated with sport, include recombinant human growth hormone (rhGH) or rhGH in combination with insulin (Sonksen 2001; Rennie 2003). Both are being used as ergogenic aids and as doping agents. They are currently taken in the belief that they increase skeletal muscle mass and improve performance (Jenkins 2001).

In Gruber and Pope's study (1999), 14\% of surveyed subjects also abused insulin and AAS. Insulin has a shorter history as a 'doping agent' when compared with both GH and AAS (Sonksen 2001). The use of AAS, rhGH, and insulin in the UK in bodybuilding and other sports has increased (Baker et al 2006) compared with a survey in 2001 (Grace et al 2001). AAS use has increased by $17 \%$, insulin by $6 \%$, and rhGH by $18 \%$. Unless caught by urinalysis in the act, convicting a competitive sporting individual who has taken rhGH (Powrie et al 2007) and insulin (Coghlan 2001) is not possible. Insulin in acute abuse is infinitely more dangerous than rhGH. The few cases that have been published are case histories of individuals who have been admitted to hospital following accidental insulin overdose (Konrad et al 1998; Rich et al 1998; Evans and Lynch 2003). They have a distorted body image and reported the condition of "reverse anorexia", where they believed they were small and weak, despite being large and muscular (Pope et al 1993). The reasons for use of these anabolic agents appear to be based not only on peer review, but also scientific research (Sonksen 2001). Low self-esteem and unrealistic, muscular male body ideals, puts individuals at risk for negative body images and unhealthy eating and exercise habits. These individuals resort to drug-taking to counteract their altered body images. The legislation in the UK would appear to be permissive in allowing the bodybuilding fraternity no problems in obtaining their insulin supplies (Elkin et al 1997). Dawson (2001) identified that $10 \%$ of 450 patients attending a needle exchange programme self-prescribed insulin for nontherapeutic purposes.

\section{Physiological and biochemical aspects of growth hormone}

The ability of the somatotroph cells in the anterior pituitary to synthesize and secrete the polypeptide, $\mathrm{hGH}$, is determined by a gene called the Prophet of Pit-1 (PROP1). When hGH is translated, $70 \%-80 \%$ is secreted as a 191 -amino-acid, 4-helix bundle protein, and $20 \%-30 \%$ as a less abundant 176-amino-acid form (Baumann 1991; Wu et al 1999) (Figure 2). Hypothalamic-releasing and hypothalamicinhibiting hormones acting via the hypophysial portal system control the secretion of hGH, which is secreted into the circulation (Melmed 2006).

In healthy persons, the hGH level is usually $<0.2 \mu \mathrm{g} . \mathrm{L}^{-1}$ throughout most of the day. There are approximately 10-12 intermittent secretory bursts in a 24 hour period, mostly at night, when the level can rise to as much as $30 \mu \mathrm{g} . \mathrm{L}^{-1}$ (Melmed 2006). HGH secretion declines at 14\% per decade from the age of 20 years (Iranmanesh et al 1991).

$\mathrm{HGH}$ action is mediated by an hGH receptor, which is expressed mainly in the liver and is composed of dimers that change conformation when occupied by an hGH ligand (Brown et al 2005).

Cleavage of the hGH receptor provides a circulating hGH binding protein (GHBP), prolonging the half-life and mediating the transport of hGH (Argetsinger et al 1993).

Intracellular hGH signalling is decreased by suppressors of cytokine signaling. HGH induces the synthesis of peripheral insulin-like growth factor I (IGF-I) (Le Roith et al 2001) while endocrine, autocrine, and paracrine IGF-I 




Figure 2 The growth hormone somatropin, in its correct 22-kD-hGH form. Three-dimensional structure, generated from the protein data base SWISS PROT. Structural data supplied with the help of the program RasMol.The n-terminal amino acid (at the bottom left hand corner) is marked yellow, as are the disulphide bridges (and the sequence range missing on the $20 \mathrm{kDa}$ hGH variant). The ranges with an $\alpha$-Helix-structure are marked in red.

induces cell proliferation and is thought to inhibit apoptosis (O’Reilly et al 2006).

IGF-binding proteins (IGFBP) and their proteases regulate the access of ligands to the IGF-I receptor affecting its action. Levels of IGF-I are at their peak during late adolescence and decline throughout adulthood, mirror imaging hGH (Milani et al 2004). IGF-I levels reflect the secretory activity of growth hormone and are one of a potential number of markers for identification of hGH-deficiency (GHD), hGH-excess (acromegaly), or rhGH administration in sport (Powrie et al 2007).

In conjunction with hGH, IGF-I has varying differential effects on protein, glucose, lipid, and calcium metabolism and therefore body composition (Mauras and Haymond 2005).

\section{Growth hormone, anxiety, and depression}

Much of our knowledge of the psychological effects of hGH has been learned from the GHD model. Using the Nottingham Health Profile (NHP) and the Psychological Wellbeing Schedule (PGWS), hGH replacement for 6 months in deficient adults has been shown to improve mental state and quality of life (QoL), such as mood and energy levels, (McGauley 1989). GHD adults have been noted to have a disturbed sleep pattern, which returns to normal on rhGH replacement (Aström et al 1990). Decreased psychological well-being has been reported in hypopituitary patients despite pituitary replacement with all hormones but growth hormone (Stabler et al 1992). HGH replacement in GHD has been shown to improve emotional control and well-being, accompanied by lower scores on anxiety, in adult males with altered body image (underestimated body size), low selfesteem and depression (Riva and Molinari 1995). Interestingly, the hGH response to physiological stimuli is reduced in healthy young males with higher psychometrically measured depressiveness (Harro et al 1999) and depressed patients have a blunted hGH response to hGH releasing hormone (Dahl et al 2000). Consequently there has been an increasing attraction in hormone replacement therapy to improve health and QoL of the healthy elderly, with age-related decline in hormone levels, the somatopause (Savine and Sonksen 2000). A new 21-item age-related hormonal decline (A-RHDQoL) questionnaire is an individualized questionnaire measuring perceived impact of age-related hormonal decline in the QoL of older males. The internal consistency reliability and content validity of the A-RHDQoL are established, but the measure is at an early stage of its development and its sensitivity to change and other psychometric properties needs to be evaluated in clinical trials of hormone replacement in older males (McMillan et al 2003). Discontinuation of rhGH treatment of young adults with GHD and then recommencing treatment, demonstrated that intra-subject IGF-I levels were negatively correlated with depression, fatigue, tension, and anxiety and positively with vigor and memory (Stouthart 
et al 2003). A large proportion of GHD adults complain of low energy levels, emotional lability, and mental fatigue and have an impaired QoL, and psychiatric morbidity, which improves after one month of growth hormone treatment (Mahajan et al 2004). The Hospital Anxiety and Depression Scale (HADS) questionnaire is a simple, reliable tool for use in medical practice (Zigmond and Snaith 1983) and has been used to determine the disturbed emotional state of groups of psychosomatic patients (Karakula et al 1996). HADS scores screen for psychiatric morbidity (Janson et al 1994), predicts psychosocial and physical outcome (Herrmann 1997), and have been used extensively with high validity in psychiatric outpatients (Martin et al 2003). This information is freely available to informed individuals in the recreational fitness industry and elite sport who wish to improve their physiques (Baker et al 2006). Such individuals who abuse AAS, rhGH, and insulin, are aware that rhGH increases fat loss and that insulin prevents proteolysis, as a consequence they abuse both these hormones either alone or in combination, with or without AAS.

\section{Effects of hGH on anthropometry, strength, and exercise performance}

$\mathrm{RhGH}$ administration has therapeutic value as a replacement therapy for GHD adults, increasing lean body mass (LBM) and reducing total and visceral fat (Johannsson et al 1997). Aerobic performance ( $\dot{V} \mathrm{O}_{2}$ peak) increased in GHD and reversed following cessation (Gullestad et al 1997).

Five years of rhGH replacement therapy in elderly adults with GHD normalized knee flexor strength, knee extensor strength, and handgrip strength (Gotherstrom et al 2005). rhGH increases lipid mobilization and oxidation, decreasing protein oxidation and increasing protein synthesis (Horber and Haymond 1990).

The use of acipimox (an antilipolytic) with rhGH administration in a 37-hour fasting state, which eliminated the ability of hGH to restrict fasting protein loss, indicated that stimulation of lipolysis by $\mathrm{hGH}$ is its principle proteinconserving mechanism (Nørrelund et al 2003). Such effects are associated with significantly increased lean body mass and have been translated into significantly increased aerobic performance (Liu et al 2003). Myostatin, a cytokine implicated in differentiated skeletal muscle growth, is a member of the transforming growth factor-beta (TGFß) family that has gained attention due to its remarkable expression profile and dramatic actions. Myostatin messenger-ribonuceleic acid (mRNA) expression is significantly inhibited by rhGH. Myostatin mRNA expression was significantly inhibited to
$31 \%$ by rhGH, compared with controls and sustained after 18 months, significantly increasing $\dot{V} \mathrm{O}_{2}$ peak, in GHD (Liu et al 2003). In humans, hyper-catabolic states such as human immunodeficiency virus (HIV) associated wasting, have been categorised by marked upregulation of myostatin (GonzalezCadavid et al 1998).

Reproduction of such results has not been forthcoming in healthy young adults, but has been identified in an infant with a mutation of the myostatin gene and was associated with gross muscle hypertrophy (Schuelke et al 2004).

\section{Effects in apparently healthy individuals}

The first researchers experimented on athletes using biosynthetic methionyl hGH (met-hGH), consisting of 192 amino-acids, as opposed to recombinant hGH, consisting of 191 amino acids (Crist et al 1988).

Met-hGH (2.67 mg [ 8 IU] 3 days per week) for 6 weeks in 8 well-trained exercising adults (22-33 years of age) who trained with progressive resistance exercise significantly decreased body fat and significantly increased LBM. Five subjects had a suppressed hGH response to stimulation from either L-dopa, arginine or sub-maximal exercise (Crist et al 1988).

One might postulate that rhGH administration would benefit elderly males, decreasing adiposity and increasing LBM (principally muscle). Rudman and colleagues (1990, 1991) demonstrated such evidence. However, they did not demonstrate increased strength.

Acute administration of either rhGH, or IGF-I, in normal healthy humans in the post-absorptive state, significantly increased forearm net balance of amino acids (Fryburg et al 1991). The effects are claimed to occur through the stimulation of protein synthesis rather than decreased protein breakdown.

However, increased LBM does not appear to have been translated into increased strength or power in young healthy individuals who have never previously used performance-enhancing drugs. For example, administration of rhGH appears to cause no further increase in muscle mass or strength than provided by resistance training in any healthy young athletes with a mean age of 23 years (Crist et al 1988; Yarasheki et al 1992, 1993; Deyssig 1993) or indeed in healthy elderly males with a mean age of 67 years (Taaffe et al 1994; Yarasheki et al 1995). There has been no substantial evidence that it can increase strength in healthy males and females greater than sixty years of age (Zachwieja and Yarasheki 1999).

The rate of protein synthesis, identified as the rate of incorporation of amino acids labelled with stable isotopes into 
muscle, is required to determine the response of muscle, over short periods of time, such as hours or days (Rennie 2003). This technique was not available to early researchers and is still not freely available.

RhGH administration did not enhance the muscle anabolism associated with heavy-resistance exercise in 16 males with a mean age of 27 years and a weight of $70.6 \mathrm{~kg}$.

Resistance training, plus rhGH group $\left(0.04 \mathrm{mg} \cdot \mathrm{kg}^{-1} \cdot \mathrm{day}^{-1}\right.$ $\left[\sim 8.4\right.$ IU.day $\left.^{-1}\right]$ ) did not differ from 9 resistance training males, compared with 9 placebo males for 12 weeks (Yarasheki et al 1992).

The fractional rate of skeletal muscle protein synthesis and the whole body rate of protein breakdown did not increase during a constant intravenous infusion of $\left[{ }^{13} \mathrm{C}\right]$ leucine in 7 young healthy experienced male weightlifters with a mean age of 23 years and a mean weight of $86.2 \mathrm{~kg}$ before and at the end of 14 days of subcutaneous rhGH administration (0.04 mg.kg ${ }^{-1}$.day ${ }^{-1}\left[\sim 10.5\right.$ IU.day $\left.\left.^{-1}\right]\right)$ (Yarasheki et al 1993).

RhGH administration in 8-10 healthy, nonobese males with a mean age of 23 years, body weight of $122 \mathrm{~kg}$, and body fat of $10.1 \%\left(0.03 \mathrm{mg} \cdot \mathrm{kg}^{-1}\right.$. day $\left.{ }^{-1}\left[\sim 11 \mathrm{IU}^{\mathrm{d}} \mathrm{day}^{-1}\right]\right)$ for a period of 6 weeks, had no effect on maximal strength during concentric contraction of the biceps and quadriceps muscles (Deyssig et al 1993). In such highly trained athletes with such a low fat mass there were no effects of rhGH treatment on strength or body composition.

The administration of rhGH to 8 healthy, sedentary males (0.0125-0.024 mg.kg ${ }^{-1}$.day ${ }^{-1}$; [2.9-5.6 IU.day ${ }^{-1}$ ]) versus placebo administration to 15 healthy, sedentary males, with low serum IGF-I levels, with a mean age of 67 years and a body mass of $78.5 \mathrm{~kg}$, for 16-weeks, did not increase muscle strength over resistance exercise training (Yarasheki et al 1995). These results may be as a consequence of the different dosages of rhGH used, because of adverse side effects incurred dosages ranged from $0.013-0.024 \mathrm{mg} . \mathrm{kg}^{-1}$.day (0.04-0.072 IU. $\left.\mathrm{kg}^{-1} \cdot \mathrm{day}^{-1}\right)$. The dosages for the first two subjects were equivalent to $5 \mathrm{IU}_{\text {day }}{ }^{-1}$ but the second two subjects had 4 IU.day ${ }^{-1}$ and the last four subjects had the equivalent of $3 \mathrm{IU}$ day $^{-1}$.

RhGH administration ( $0.03 \mathrm{mg} . \mathrm{kg}^{-1}$ of body weight [7.2 $\mathrm{IU} \times 3$. week $\left.^{-1}\right]$ ), for 6 months in 52 healthy males with a mean age of 75 years and a body mass of $80 \mathrm{~kg}$, with well-preserved functional ability, but low baseline IGF-I levels, significantly increased LBM, by $4.3 \%$. There were no statistically or clinically significant differences seen between the groups in knee or hand grip strength, nor in aerobic performance (Papadakis et al 1996).
Wallace and colleagues (1999) demonstrated that there was no improvement in morphological or performance characteristics, assessed by cycle ergometry and $\dot{V} \mathrm{O}_{2}$ peak assessment, following rhGH administration to 8 males (0.05 mg. $\mathrm{kg}^{-1}$. day ${ }^{-1}\left[0.15 \mathrm{IU} \cdot \mathrm{kg}^{-1} \cdot \mathrm{day}^{-1}\right]$ ) versus placebo administration to 8 males, for 7 days.

The combined effects of testosterone and rhGH, administration for 1 month, significantly improved aerobic performance in "stair climb time" in 10 healthy older males (Brill et al 2002).

A single rhGH dose (2.5 mg [7.5 IU]) in 7 highly trained males with a mean age of 26 years, body mass of $77 \mathrm{~kg}$, and a $\dot{V} \mathrm{O}_{2}$ peak of $65 \mathrm{ml} \cdot \mathrm{min}^{-1} \cdot \mathrm{kg}^{-1}$, who performed $90 \mathrm{~min}$ of cycling 4 hours after taking the rhGH, prevented two subjects from completing the exercise protocol. It significantly increased plasma lactate and glycerol as well as serum NEFA. This may compromise exercise performance. $\dot{V} \mathrm{O}_{2}$ peak remained unaltered by drug effect until exhaustion (Lange et al 2002a). Plasma glucose was, on average, 9\% higher during exercise after rhGH administration compared with placebo. Any benefit of exercise in terms of increased glucose tolerance appeared to be negated by rhGH in the subjects.

Myosin heavy chain (MHC) 2X isoforms, were significantly increased by rhGH administration in healthy elderly males (Lange et al 2002b). This has been regarded as a change into a more youthful MHC composition, possibly induced by the rejuvenation of systemic IGF-I levels. There was no effect on isokinetic quadriceps muscle strength, power, cross-sectional area (CSA), or fibre size. Resistance training (RT) and placebo caused substantial increases in quadriceps isokinetic strength, power, and CSA; but these RT-induced improvements were not further augmented by additional rhGH administration. In the RT and rhGH group, there was a significant decrease in $\mathrm{MHC} 1$ and $2 \mathrm{X}$ isoforms, whereas MHC 2A increased.

Resistance training, therefore, seems to overrule the changes in $\mathrm{MHC}$ composition induced by $\mathrm{rhGH}$ administration alone.

Blackman and colleagues (2002) administered rhGH (0.03-0.02 mg. $\mathrm{kg}^{-1}$. day $\left.{ }^{-1}\right)$ and gender related sex steroids to healthy aged males and females, aged 65-88, for 26 weeks. LBM increased and fat mass decreased. Testosterone and rhGH increased $\dot{V} \mathrm{O}_{2}$ peak in males, but transdermal oestradiol, $100 \mu \mathrm{g} . \mathrm{d}^{-1}$, plus oral medroxyprogesterone acetate, $10 \mathrm{mg}^{-\mathrm{d}^{-1}}$ and rhGH did not increase female $\dot{V} \mathrm{O}_{2}$ peak. The effect on strength and endurance exercise could not entirely be attributed to the administration of rhGH.

The administration of rhGH in a dosage of $0.067 \mathrm{mg} . \mathrm{kg}^{-1}$. day $^{-1}\left(\sim 15.3\right.$ IU.day $\left.^{-1}\right)$ exerts an anabolic effect both at rest 
and during exercise in 6 endurance-trained athletes versus 5 controls, with a mean age of 31 years, measuring whole body leucine turnover. Plasma levels of glycerol and free fatty acids and glycerol rate of appearance ( $\mathrm{Ra}$ ) at rest, during and post exercise increased during rhGH treatment compared with placebo. Glucose Ra and glucose rate of disappearance $(\mathrm{Rd})$ were greater during $\mathrm{rhGH}$ treatment compared with placebo (Healy et al 2003).

Resting energy expenditure and fat oxidation were greater under resting conditions during rhGH treatment compared with placebo, in 9 males with a mean age of 24 years, a weight of $77.3 \mathrm{~kg}$, body fat of $17.7 \%$, and a $\dot{V} \mathrm{O}_{2}$ peak $37.9 \mathrm{ml} \cdot \mathrm{kg}^{-1} \cdot \mathrm{min}^{-1}$, who completed $6 \times 30$-minute randomly assigned cycle ergometry exercise trials. An rhGH infusion (0.01 mg. $\left.\mathrm{kg}^{-1},[\sim 2.3 \mathrm{IU}]\right)$ was followed by a 30 -minute exercise trial. There were no significant condition effects for total work, caloric expenditure, heart-rate response, the blood lactate response, or ratings of perceived exertion response (RPE). However, acute rhGH administration resulted in lower $\dot{V} \mathrm{O}_{2}$ peak without a drop-off in power output (Irving et al 2004). The reduced $\dot{V} \mathrm{O}_{2}$ peak may be explained by the rhGH administration improving exercise economy. This may have been as a consequence of production of free fatty acids (FFA) by rhGH's lipolytic effect, providing the substrates for the maintenance of energy metabolism, despite the lower $\dot{V} \mathrm{O}_{2}$ peak.

There was no increase observed in the strength in 30 physically active and healthy individuals of both genders with a mean age 25.9 years. Ten subjects each received rhGH $\left(0.033 \mathrm{mg} \cdot \mathrm{kg}^{-1} \cdot \mathrm{day}^{-1}\right)$ or rhGH $\left(0.067 \mathrm{mg} . \mathrm{kg}^{-1} \cdot \mathrm{day}^{-1}\right)$ or placebo for 1 month. IGF-I significantly increased by $134 \%$, and there were significant increases observed for body weight (2.7\%), LBM (5.3\%), total body water (6.5\%), and extracellular water (ECW) $(9.6 \%)$. Body fat significantly decreased by $6.6 \%$ (Ehrnborg et al 2005).

There was no increase in power or $\dot{V} \mathrm{O}_{2}$ peak in 30 physically active and healthy individuals of both genders, with a mean age of 26 years who received rhGH $\left(0.033 \mathrm{mg} \cdot \mathrm{kg}^{-1} \cdot \mathrm{day}^{-1}\right)$ or $\mathrm{rhGH}\left(0.067 \mathrm{mg} \cdot \mathrm{kg}^{-1} \cdot \mathrm{day}^{-1}\right)$ or placebo for 1 month (Berggren et al 2005).

Plasma levels of glycerol and free fatty acids increased at rest and during exercise during $\mathrm{rhGH}$ administration ( $0.067 \mathrm{mg} . \mathrm{kg}^{-1}$.day $\left.{ }^{-1}\right)$ for 4 weeks, in 6 trained male athletes compared with controls. This had the effect of increasing resting energy expenditure and fat oxidation and increasing glucose production and uptake after exercise (Healy et al 2006).

Six days of rhGH administration $\left(0.019 \mathrm{mg} \cdot \mathrm{kg}^{-1} \cdot \mathrm{day}^{-1}\right.$ $\left[\sim 5\right.$ IU.day $\left.\left.^{-1}\right]\right)$ by 24 abstinent male AAS-users, with a mean age of 32 years compared with controls, increased forced expiratory volume in one second/forced vital capacity $\left(\mathrm{FEV}_{1} / \mathrm{FVC}\right)$, maximum inspiratory pressure, maximum expiratory pressure, and $\dot{V} \mathrm{O}_{2}$ peak (Graham et al 2007b). It is possible that previous use of AAS, had increased the number of myonuclei per muscle fiber, to such an extent that a 12-week washout program was an insufficient time interval for return of the proportion of central nuclei to baseline (Eriksson et al 2005).

Athletes continue to abuse both cadaver pituitary hGH and rhGH in the belief that such effects can be extrapolated to the healthy individual (Crist et al 1988; Deyssig et al 1993). The abuse of cadaver pituitary hGH has diminished in Europe, subsequent to its association with Jacob-Creutzfeldt disease and the abundant Internet availability of rhGH from China. The acclaim of the anabolic properties of growth hormone appeared in the underground doping literature as early as 1983 (Duchaine 1983). Its abuse has increased (Baker et al 2006) despite early research demonstrating its effect on functional abilities, is no greater than exercise alone in healthy young males (Yarasheki et al 1992) or elderly males (Yarasheki et al 1995) and the demonstration that supraphysiological dosages can have fatal consequences (Takala et al 1999).

Both hGH and rhGH are believed to stimulate production of class-1 isoforms of IGF-I locally in muscles and tendons. These may have a preventative effect on rupture of muscles and tendons in AAS-induced hypertrophy (Doessing and Kjaer 2005). The transmission of force from muscle fibres to bone, could be explained by the stimulating effect of $\mathrm{hGH}$ on collagen synthesis. Such strengthened connective tissue would provide a more strain-resistant musculo-tendinous junction and could explain why there is still a claimed effect of rhGH on athletic performance. Previous studies in humans have not shown an increase in endurance exercise or strength in drug naive young athletes, solitarily due to rhGH, but it has been suggested that such differences were not significant due to a lack of power, given the relatively small sample sizes. The relevance of these effects for athletic performance would suggest enhancement under circumstances where an athlete cycles AAS and then administers rhGH in the abstinent phase in an attempt to circumvent a doping violation.

\section{Physiology and biochemistry of Insulin}

Insulin is a 2 chain (30 and 21 amino-acids) polypeptide hormone (51 amino-acids, 5808 molecular weight) synthesized and secreted by the beta-cells of the islets of Langerhans in 
the pancreas gland. The entry of a water-soluble substrate such as glucose across an impermeable lipid bi-layer into a cell requires a specific transport mechanism. These protein carriers are known as glucose 'transporters' (GLUTs). In the case of glucose there are at least six types and they tend to be tissue-specific. In the case of muscle the transporter is called 'Glut 4'. It is normally present in excess in the cell membrane even in the absence of insulin and is not rate limiting for glucose entry into the cell (Sonksen 2001). Insulin acts in a stimulatory and an inhibitory manner (Schafer 1916). It stimulates the translocation of 'Glut 4' from the cytoplasm of muscle and adipose tissue to the cell membrane. This increases the rate of glucose uptake to values greater than in the basal state without insulin, shown in isolated adipocytes from rats (Figure 3) (Thomas et al 1979).

There are a sufficient number of glucose transporters in all cell membranes at all times to ensure enough glucose uptake, to satisfy the cell's respiration, even in the absence of insulin. Insulin increases the number of these transporters in some cells but glucose uptake is never truly insulin-dependent (Sonksen, 2001).

In Figure 3, it can be seen that simultaneously with insulin's excitatory action in stimulating lipogenesis, insulin also exhibits an inhibitory action in preventing glycerol release. It is this inhibitory action on lipolysis (and also glycolysis, gluconeogenesis, ketogenesis, and proteolysis) that accounts for most of insulin's physiological actions in man. The inhibitory actions are also responsible for insulin's net anabolic actions.

Insulin increases glucose metabolism more through reducing FFA and ketone levels than it does through recruiting more GLUTs into the muscle cell membrane. Insulin does, however, have a direct action recruiting more GLUTs into muscle cell membranes. This facilitates glucose uptake which is reflected as an increase in the metabolic clearance rate (MCR) of glucose, measured with isotope tracer technology and is a nonlinear function of blood glucose concentration, increasing as glucose concentration falls and insulin levels rise (Sonksen and Sonksen 2000). Glucose transport into the cell is mainly determined by the concentration gradient between the extracellular fluid and the intracellular 'free' glucose. 'Free' glucose is very low inside the cell as it is immediately phosphorylated. In uncontrolled diabetes, particularly where there is a high concentration of FFA and ketones, glycolysis is inhibited, phosphorylation of 'free' glucose stops and intracellular 'free' glucose rises. Insulin recruits more transporters into the cell membrane from an intracellular pool. This increases the rate of glucose entry for a given glucose concentration and this is reflected in vivo by an increase in the MCR of glucose, which is an in vivo measure of substrate transporter activity (Boroujerdi et al 1995).

Experiments in normal subjects using hyperglycaemic and hyperinsulinaemic 'clamps' have shown the importance

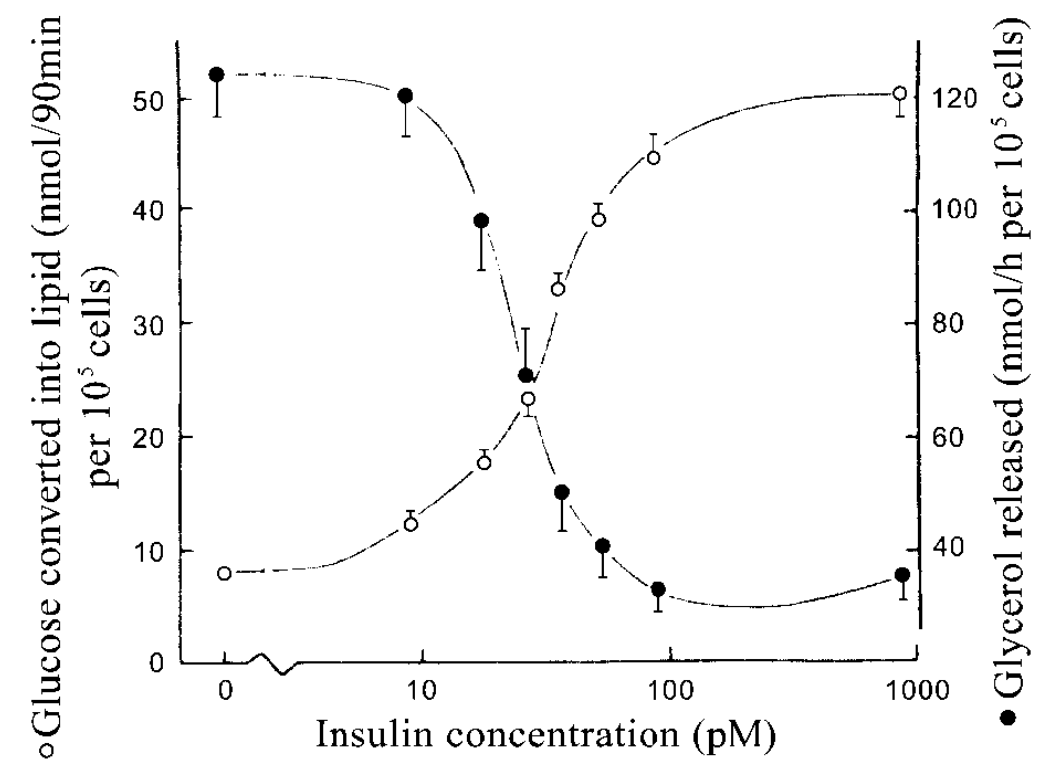

Figure 3 Insulin exhibits both inhibitory and excitatory actions via the same receptor. In these experiments carried out on rat adipose tissue, in vitro insulin simultaneously inhibits lipolysis (the release of glycerol from stored triglyceride) and stimulates lipogenesis (formation of stored triglyceride from glucose). Thus its anabolic action is due to two mechanisms working synergistically. Copyright (C) 1979 Royal Society of Medicine. Reproduced with permission from Thomas SHL,Wisher MH, Brandenburg D, et al. 1979. Insulin action on adipocytes. Evidence that the anti-lipolytic and lipogenic effects of insulin are medicated by the same receptor. Biochem J, I84:355-60. 
of both glucose and insulin concentrations in determining glucose uptake (Gottesman et al 1982).

\section{Insulin, anxiety, and depression}

There is a correlation between substance misuse and inappropriate compliance with treatment in chronic medical conditions, which can induce anxiety and depressive disorders (Weiss et al 1998). Insulin dependent diabetics (type 1) have higher co-morbid substance misuse compared with the general population (Kovacs et al 1997) and their compliance with their medical management is reduced (Morris et al 1997). Insulin dependent diabetics have an increased incidence of a psychiatric disorder, predominantly in the early course of their condition (Kovacs et al 1997). Treating the psychiatric disorder improves diabetic control (Lustman et al 1997).

Hypoglycemia is a regular occurrence in insulindependent diabetics (Potter et al 1982) and may be associated with cognitive and affective outcomes (Gonder-Freerick et al 1997). Mood changes induced by fluctuations in glycemic control are characteristically individual, with depressive and anxiety affective states being most prevalent, however euphoria can also occur (Gonder-Freerick et al 1989). The literature is interspersed with cases of deliberate misuse of insulin, associated with either suicide, parasuicide or factitious illness (Kaminer and Robbins 1989; Cassidy et al 1997). Even intelligent individuals have abused their therapeutically prescribed insulin to induce feelings of "happiness, disorientation, drunkenness, altered perception of helplessness, and euphoria" (Cassidy et al 1997). However, there always appears to be an underlying mood or personality disorder (Scaramuzza et al 1996).

There appears to be a class of individuals who are not diabetic and inject insulin to induce euphoria, to alter perception and for the "exquisite pleasure" associated with the risk of death (Odie 1968; Retsas 1972; Scarlett et al 1977).

A cohort of patients referred to a deliberate self-harm team was asked to complete the HADS questionnaire. The HADS gave a sensitivity of $88 \%$ and a positive predictive value of $80 \%$ (Hamer 1991). Eighty percent of 56 hypoglycemic patients admitted to an urban teaching hospital in a 12 month period were diabetics receiving insulin. Twenty percent were as a consequence of deliberate self-poisoning with insulin and had a history of psychiatric disorder (Hart and Frier 1998). A bodybuilder, who took 70 IU insulin for its anabolic effect, suffered hypoglycemic convulsions due to neuroglycopaenic coma (Konrad et al 1998).

\section{Insulin effects on anthropometry, strength, and exercise performance}

Glucose metabolism significantly increased following exogenous insulin in trained athletes. $\dot{V} \mathrm{O}_{2}$ peak also significantly increased (Sato et al 1986).

Insulin's anabolic actions are believed to improve performance, by increasing protein synthesis (Bonadonna et al 1993; Kimball et al 1994) and inhibiting protein catabolism and enhancing transport of selected amino acids in human skeletal muscle (Biolo et al 1995). Physiological hyperinsulinemia stimulates the activity of amino acid transport in human skeletal muscle, thereby stimulating protein synthesis (Bonadonna et al 1993).

Insulin-treated diabetics are known to have increased lean body mass versus controls (Sinha et al 1996). In addition to its role in regulating glucose metabolism, insulin increases amino acid transport into cells. Its stimulation of lipogenesis, and diminished lipolysis, is one of the reasons why bodybuilders and athletes will take rhGH in conjunction, to counteract this adverse effect, whilst optimizing protein synthesis (Sonksen 2001).

It is the inhibition of proteolysis that the athlete is interested in and the physiology of the diabetic patient has been extrapolated by the athlete to the sporting arena. Insulin administration is protein anabolic in the insulin-resistant state of chronic renal failure. It inhibits proteolysis and when administered with amino-acids, it increases net protein synthesis (Lim et al 2003).

The administration of exogenous insulin, establishes an in-vivo hyperinsulinemic clamp, increasing muscle glycogen before and in the recovery stages of strenuous exercise. This may increase power, strength, and stamina and assist in recovery from strenuous exercise.

Secondly, by inhibiting muscle protein breakdown and in conjunction with a high protein and high carbohydrate diet, insulin will have the action of increasing muscle bulk, potentially improving performance.

\section{Conclusion}

Strength and performance increase by the administration of rhGH and insulin in healthy young adults would appear possible by pharmacological manipulation, however current review of the literature suggests otherwise, in young, healthy, drug-naive individuals . Psychological improvement in abstinent AAS abusers by rhGH has been demonstrated (Graham et al 2007a), but no published research has been conducted in interventive insulin abuse in sport. Further research into the continued abuse of these drugs may assist 
in our understanding of the psychological and social reasons why individuals take these drugs, when current information appears unconvincing.

\section{Disclosures}

The authors have no conflicts of interest to declare.

\section{References}

Argetsinger LS, Campbell GS, Yang X, et al. 1993. Identification of JAK2 as a growth hormone receptor-associated tyrosine kinase. Cell, 74:237-44.

Astrom C, Pedersen SA, Lindholm J. 1990. The influence of growth hormone on sleep in adults with growth hormone deficiency. Clinical Endocrinol $(O x f), 43: 143-9$.

Baker JS, Graham MR, Davies B. 2006. "Steroid" and prescription medicine abuse in the health and fitness community; a regional study. Eur J Intern Med, 17:479-84.

Baumann G. 1991. Growth hormone heterogeneity: genes, isohormones, variants, and binding proteins. Endocr Rev, 12:424-49.

Berggren A, Ehrnborg C, Rosen T, et al. 2005. Short-term administration of supraphysiological recombinant human growth hormone $(\mathrm{GH})$ does not increase maximum endurance exercise capacity in healthy, active young men and females with normal GH-insulin-like growth factor I axes. J Clin Endocrinol Metab, 90:3268-73.

Bhasin S, Storer TW, Berman N, et al. 1996. The effects of supraphysiologic doses of testosterone on muscle size and strength in normal men. $N$ Engl J Med, 335:1-7.

Biolo G, Fleming RYD, Wolfe RD. 1995. Physiologic hyperinsulinaemia stimulates protein synthesis and enhances transport of selected amino acids in human skeletal muscle. J Clin Invest, 95:811-19.

Blackman MR, Sorkin JD, Münzer T, et al. 2002. Growth hormone and sex steroid administration in healthy aged women and men. $J$ Am Med Assoc, 288:2282-92.

Bonadonna RC, Saccomani MP, Cobelli C, et al. 1993. Effect of Insulin on System A Amino Acid Transport in Human Skeletal Muscle. J Clin Invest, 91:514-21.

Boroujerdi MA, Umpleby AM, Jones RH, et al. 1995. A simulation model for glucose kinetics and estimates of glucose utilization rate in type I diabetic patients. Am J Physiol, 268:766-74.

Brill KT, Weltman AL, Gentili A, et al. 2002. Single and combined effects of growth hormone and testosterone administration on measures of body composition, physical performance, mood, sexual function, bone turnover, and muscle gene expression in healthy older men. $J$ Clin Endocrinol Metab, 87:5649-57.

Brown RJ, Adams JJ, Pelekanos RA, et al. 2005. Model for growth hormone receptor activation based on subunit rotation within a receptor dimer. Nat Struct Mol Biol, 12:814-21.

Cassidy EM, O'Halloran DJ, Barry S. 1999. Insulin as a substance of misuse in a patient with insulin dependent diabetes mellitus. BMJ, 319:1417-18.

Coghlan A. 2001. Athletes may be increasingly abusing insulin [online]. New Scientist, August 8. Accessed on December 12, 2007. URL: http://www.newscientist.com/article/dn1129-athletes-may-be-increasingly-abusing-insulin.html.

Crist DM, Peake GT, Egan PA, et al. 1988. Body composition response to exogenous GH during training in highly conditioned adults. J Appl Physiol, 65:579-84.

Dahl RE, Birmaher B, Williamson DE, et al. 2000. Low growth hormone response to growth hormone-releasing hormone in child depression. Biol Psychiatry, 48:981-8.

Dawson RT. 2001. Drugs in sport. The role of the physician. J Endocrinol, 170:55-61.

Deyssig R, Frisch H, Blum WF, et al. 1993. Effect of growth hormone treatment on hormonal parameters, body composition and strength in athletes. Acta Endocrinol (Copenh), 128:313-18.
Doessing M, Kjaer M. 2005. Growth hormone and connective tissue in exercise. Scand J Med Sci Sports, 15:202-10.

Duchaine D. 1983. Underground steroid handbook, 1st ed. California: HLR Technical Books, p 84.

Ehrnborg C, Ellegard L, Bosaeus I, et al. 2005. Supraphysiological growth hormone: less fat, more extracellular fluid but uncertain effects on muscles in healthy, active young adults. Clin Endocrinol (Oxf), 62:449-57.

Elkin SL, Brady S, Williams IP. 1997. Bodybuilders find it easy to obtain insulin to help them in training. $B M J, 314: 1280$.

Eriksson A, Kadi F, Malm C, et al. 2005. Skeletal muscle morphology in power-lifters with and without anabolic steroids. Histochem. Cell Biol, 124:167-75.

Evans PJ, Lynch RM. 2003. Insulin as a drug of abuse in body building. Br J Sports Med, 37:356-7.

Fryburg DA, Gelfand RA, Barrett EJ. 1991. Growth hormone acutely stimulates forearm muscle protein synthesis in normal humans. Am J Physiol, 260:499-504.

GonderFreerick LA, Clarke WL, Cox DJ. 1997. The emotional, social and behavioural implications of insulininduced hypoglycemia. Semin Clin Neuropsychiatry, 2:57-65.

GonderFreerick LA, Cox DJ, Bobbitt SA. 1989. Mood changes associated with fluctuations in insulindependent diabetes mellitus. Health Psychol, 8:45-9.

Gonzalez-Cadavid NF, Taylor WE, Yarasheski K, et al. 1998. Organization of the human myostatin gene and expression in healthy men and HIV-infected men with muscle wasting. Proc Natl Acad Sci USA, 95:14938-43.

Gotherstrom G, Bengtsson BA, Sunnerhagen KS, et al. 2005. The effects of five-year growth hormone replacement therapy on muscle strength in elderly hypopituitary patients. Clin Endocrinol (Oxf), 62:105-13.

Gottesman I, Mandarino L, Verdonk C, et al. 1982. Insulin increases the maximum velocity of glucose uptake without altering the Michaelis constant in man. J Clin Invest, 70:1310-14.

Grace FM, Baker JS, Davies B. 2001. Anabolic androgenic steroid (AAS) use in recreational gym users - A regional sample of the Mid-Glamorgan area. $J$ Substance Use, 12:145-53.

Graham MR, Baker JS, Evans P, et al. 2007a. Recombinant human growth hormone in abstinent androgenic-anabolic steroid use: Psychological, endocrine, and trophic factor effects. Curr Neurovasc Res, 4:9-18.

Graham MR, Davies B, Hullin D, et al. 2007b. Short-term recombinant human growth hormone administration improves respiratory function in abstinent anabolic-androgenic steroid users. Growth Horm IGF Res, 17:201-9.

Gruber AJ, Pope HG Jr. 1999. Compulsive weight lifting and anabolic drug abuse among women rape victims. Compr Psychiatry, 40:273-7.

Gruber AJ, Pope HG Jr. 2000. Psychiatric and medical effects of anabolic-androgenic steroid use in women Psycother Psychosom, 69:19-26.

Gullestad L, Birkeland K, Bjonerheim R. 1998. Exercise capacity and hormonal response in adults with childhood onset growth hormone deficiency during long-term somatropin treatment. Growth Horm IGF Res, 8:377-84.

Hamer D, Sanjeev D, Butterworth E, et al. 1991. Using the Hospital Anxiety and Depression Scale to screen for psychiatric disorders in people presenting with deliberate self-harm. Br J Psychiatry, 158:782-4.

Harro J, Rimm H, Harro M, et al. 1999. Association of depressiveness with blunted growth hormone response to maximal physical exercise in young healthy men. Psychoneuroendocrinology, 24:505-17.

Hart SP, Frier BM. 1998. Causes, management and morbidity of acute hypoglycaemia in adults requiring a hospital admission. Quart J Med, 91:505-10.

Hartgens F, Kuipers, H. 2004. Effects of androgenic-anabolic steroids in athletes. Sports Med, 34:513-14.

Hartgens F, Rietjens G, Keizer HA, et al. 2004. Effects of androgenicanabolic steroids on apolipoproteins and lipoprotein (a). Br J Sports Med, 38:253-9. 
Haupt HA, Rovere GD. 1984. Anabolic steroids: a review of the literature. Am J Sports Med, 12:469-84.

Healy ML, Gibney J, Russell-Jones DL, et al. 2003. High dose growth hormone exerts an anabolic effect at rest and during exercise in endurance-trained athletes. J Clin Endocrinol Metab, 11:5221-6.

Healy ML, Gibney J, Pentecost C, et al. 2006. Effects of high-dose growth hormone on glucose and glycerol metabolism at rest and during exercise in endurance-trained athletes. J Clin Endocrinol Metab, 9:320-7.

Herrmann C. 1997. International experiences with the Hospital Anxiety and Depression Scale, a review of validation data and clinical results. J Psychosom Res, 42:17-41.

Horber FF, Haymond MW. 1990. Human growth hormone prevents the protein catabolic side effects of prednisone in humans. $J$ Clin Invest, 86:265-72.

Iranmanesh A, Lizarralde G, Velduis JD. 1991. Age and relative adiposity are specific negative determinants of the frequency and amplitude of growth hormone secretory bursts and the half-life of endogenous GH in healthy men. J Clin Endocrinol Metab, 73:1081-8.

Irving BA, Patrie JT, Anderson SM, et al. 2004. The effects of time following acute growth hormone administration on metabolic and power output measures during acute exercise. J Clin Endocrinol Metab, 89:4298-305.

Janson C, Bjornsson E, Hetta J, et al. 1994. Anxiety and depression in relation to respiratory symptoms and asthma. Am J Respir Crit Care Med, 149:930-4.

Jenkins PJ. 2001. Growth hormone and exercise: physiology, use and abuse. Growth Horm IGF Res, 11:71-7.

Johannsson G, Grimby G, Sunnerhagen KS, et al. 1997. Two years of growth hormone $(\mathrm{GH})$ treatment increases isometric and isokinetic muscle strength in GH-deficient adults. JClin Endocrinol Metab, 82:2877-84.

Kaminer Y, Robbins DR. 1989. Insulin misuse: a review of an over-looked psychiatric problem. Psychosomatics, 30:19-24.

Karakula H, Grzywa A, Spila B, et al 1996. Use of Hospital Anxiety and Depression Scale in psychosomatic disorders. Psychiatr Pol, 30:653-67.

Kimball SR, Vary TC, Jefferson LS. 1994. Regulation of protein synthesis by insulin. Ann Rev Physiol, 56:321-48.

Konrad C, Schupfer G, Wietlisbach M, et al. 1998. Insulin as an anabolic: hypoglycaemia in the bodybuilding world. Anaesthesiol Intensivmed Schmerzther, 33:461-3.

Kovacs M, Goldston D, Obrosky DS, et al. 1997. Psychiatric disorders in youths with IDDM: rates and risk factors. Diabetes Care, 20:36-44.

Lange KH, Larsson B, Flyvberg A, et al. 2002a. Acute growth hormone administration causes exaggerated increases in plasma lactate and glycerol during moderate to high intensity bicycling in trained young men. J Clin Endocrinol Metab, 87:4966-75.

Lange KH, Andersen JL, Beyer N, et al. 2002b. GH admin changes myosin heavy chain isoforms in skeletal muscle but does not augment muscle strength or hypertrophy, either alone or combined with resistance exercise training in healthy elderly men. J Clin Endocrinol Metab, 87:513-23.

Le Roith D, Scavo L, Butler A. 2001. What is the role of circulating IGF-I? Trends Endocrinol Metab, 12:48-52.

Lim VS, Yarasheski KE, Crowley JR, et al. 2003. Insulin is protein-anabolic in chronic renal failure patients. $J$ Am Soc Nephrol, 14:2297-304.

Liu W, Thomas SG, Asa SL, et al. 2003. Myostatin is a skeletal muscle target of growth hormone anabolic action. J Clin Endocrinol Metab, 88:5490-6.

Lustman PJ, Griffith LS, Clouse RE, et al. 1997. Effects of nortriptyline on depression and glycemic control in diabetes. Psychosom Med, 59:241-50.

Mahajan T, Crown A, Checkley S, et al. 2004. Atypical depression in growth hormone deficient adults, and the beneficial effects of growth hormone treatment on depression and quality of life. Eur J Endocrinol, $151: 325-32$.
Martin CR, Lewin RJ, Thompson DR. 2003. A confirmatory factor analysis of the Hospital Anxiety and Depression Scale in coronary care patients following acute myocardial infarction. Psychiatry Res, 120:85-94.

Mauras N, Haymond MW. 2005. Are the metabolic effects of GH and IGF-I separable. Growth Horm IGF Res, 15:19-27.

McGauley GA. 1989. Quality of life assessment before and after growth hormone treatment in adults with growth hormone deficiency. Acta Paediatr Scand, 356:70-2.

McMillan CV, Bradley C, Giannoulis M, et al. 2003. Preliminary development of a new individualised questionnaire measuring quality of life in older men with age-related hormonal decline: the A-RHDQoL. Health Qual Life Outcomes, 1:51.

Melmed S. 2006. Medical progress: Acromegaly. N Engl J Med, 14:2558-73.

Milani D, Carmichael JD, Welkowitz J, et al. 2004. Variability and reliability of single serum IGF-I measurements: impact on determining predictability of risk ratios in disease development. J Clin Endocrinol Metab, 89:2271-4.

Morris AD, Boyle DI, McMahon AD, et al. 1997. Adherence to insulin treatment, glycaemic control, and ketoacidosis in insulindependent diabetes mellitus. Lancet, 350:1505-10.

Nørrelund H, Nair KS, Nielsen S, et al. 2003. The decisive role of free fatty acids for protein conservation during fasting in humans with and without growth hormone. J Clin Endocrinol Metab, 88:4371-8.

Odie ELA. 1968. Insulin habituation and psychopathy. BMJ, 2:346.

O'Reilly KE, Rojo F, She QB, et al. 2006. mTOR inhibition induces upstream receptor tyrosine kinase signaling and activates Akt Cancer Res, 66:1500-8.

Pagonis TA, Angelopoulos NV, Koukoulis GN, et al. 2006a. Psychiatric and hostility factors related to use of anabolic steroids in monozygotic twins. Eur Psychiatry, 21:563-9.

Pagonis TA, Angelopoulos NV, Koukoulis GN, et al. 2006b. Psychiatric side effects induced by supraphysiological doses of combinations of anabolic steroids correlates to the severity of abuse. Eur Psychiatry, 21:551-62.

Papadakis MA, Grady D, Black D, et al. 1996. Growth hormone replacement in healthy older men improves body composition but not functional ability. Ann Intern Med, 124:708-16.

Papazisis G, Kouvelas D, Mastrogianni A, et al. 2007. Anabolic androgenic steroid abuse and mood disorder: a case report. Int $J$ Neuropsychopharmacol, 10:291-3.

Pope HG Jr, Katz DL, Hudson JI. 1993. Anorexia nervosa and "reverse anorexia" among 108 male bodybuilders. Compr Psychiatry, 34:406-9.

Potter J, Clarke P, Gale EA, et al. 1982. Insulininduced hypoglycaemia in an accident and emergency department: the tip of an iceberg? BMJ, 285:1182-90

Powrie JK, Bassett EE, Rosen T, et al. 2007. Detection of growth hormone abuse in sport. Growth Horm IGF Res, 17:220-6.

Rennie MJ. 2003. Claims for the anabolic effect of growth hormone. A case for the Emperor's new clothes. Br J Sports Med, 37:100-5.

Retsas S. 1972. Insulin abuse by a drug addict. BMJ, 4:792-3.

Rich JD, Dickinson BP, Merriman NA, et al. 1998. Insulin use by bodybuilders. JAMA, 279:1613.

Riva G, Molinari E. 1995. Body image and social attitude in growthhormone-deficient adults. Percept Mot Skills, 80:1083-8.

Ruckzika L, Wettstein A, Kaegi H. 1935. Sexual hormone VIII Darstellung von Testosterone unter Anwendung gemischter Ester. Helv Chim Acta, 18:1478.

Rudman D, Feller AG, Nagraj HS, et al. 1990. Effect of human growth hormone in men over 60 years old. N Engl J Med, 323:1-6.

Rudman D, Feller AG, Cohn L, et al. 1991. Effect of human growth hormone on body composition in elderly men. Horm Res, 36:73-81.

Sato Y, Hayamizu S, Yamamoto C, et al. 1986. Improved insulin sensitivity in carbohydrate and lipid metabolism after physical training. Int J Sports Med, 7:307-10. 
Savine R, Sönksen P. 2000. Growth hormone - hormone replacement for the somatopause? Horm Res, 53:37-41.

Scaramuzza A, Castellani G, Lorini R. 1996. Insulin abuse in an adolescent with insulindependent diabetes mellitus. Eur J Pediatr, 155:526.

Scarlett JA, Mako ME, Rubenstein AH, et al. 1977. Factitious hypoglycemia. Diagnosis by measurement of serum Cpeptide immunoreactivity and insulinbinding antibodies. $N$ Engl J Med, 297:1029-32.

Schafer E. 1916. The endocrine organs. London: Longman, Green and Co.

Schuelke M, Wagner KR, Stolz LE, et al. 2004. Myostatin mutation associated with gross muscle hypertrophy in a child. $N$ Engl $J$ Med, 350:2682-8.

Shahidi NT. 2001. A review of the chemistry, biological action, and clinical applications of anabolic-androgenic steroids. Clin Ther, 23:1355-90.

Sinha A, Formica C, Tsalamandris C, et al. 1996. Effects of insulin on body composition in patients with insulin-dependent and non-insulindependent diabetes. Diabet Med, 13:40-6.

Sonksen PH. 2001. Insulin, growth hormone and sport. J Endocrinol, 170:13-25.

Sonksen PH, Sonksen J. 2000. Insulin: Understanding its action in health and disease. Br J Anaesthesia, 85:69-79.

Stabler B, Turner JR, Girdler SS, et al. 1992. Reactivity to stress and psychological adjustment in adults with pituitary insufficiency. Clin Endocrinol, 6:467-73.

Stouthart PJ, Deijen JB, Roffel M, et al. 2003. Quality of life of growth hormone $(\mathrm{GH})$ deficient young adults during discontinuation and restart of GH therapy. Psychoneuroendocrinology, 28:612-26.

Taaffe DR, Pruitt L, Reim J, et al. 1994. Effects of recombinant human growth hormone on the muscle strength response to resistance exercise in elderly men. J Clin Endocrinol Metab, 79:1361-6.
Takala J, Ruokonen E, Webster NR, et al. 1999. Increased mortality associated with growth hormone treatment in critically ill adults. N Engl J Med, 341:785-92.

Thomas SHL, Wisher MH, Brandenburg D, et al. 1979. Insulin action on adipocytes. Evidence that the anti-lipolytic and lipogenic effects of insulin are medicated by the same receptor. Biochem J, 184:355-60.

Wallace JD, Cuneo RC, Baxter R, et al. 1999. Responses of the growth hormone $(\mathrm{GH})$ and insulin-like growth factor axis to exercise, $\mathrm{GH}$ administration and $\mathrm{GH}$ withdrawal in trained adult males: a potential test for GH abuse in sport. J Clin Endocrinol Metab, 84:3591-601.

Weiss RD, Greenfield SF, Najavits LM, et al. 1998. Medication compliance among patients with bipolar disorder and substance use disorder. J Clin Psychiatry, 59:172-4.

Wu Z, Bidlingmaier M, Dall R, et al. 1999. Detection of doping with human growth hormone. Lancet, 353:895.

Yarasheki KE, Campbell JA, Smith K. 1992. Effect of growth hormone and resistance exercise on muscle growth and strength in young men. Am J Physiol, 262:261-7.

Yarasheki KE, Zachwieja JJ, Angelopoulos TJ. 1993. Short-term growth hormone treatment does not increase muscle protein synthesis in experienced weight lifters. $J$ Appl Physiol, 74:3073-6.

Yarasheki KE, Zachwieja JJ, Campbell JA, et al. 1995. Effect of growth hormone and resistance exercise on muscle growth and strength in older men. Am J Physiol, 268:268-76.

Zachwieja JJ, Yarasheki KE. 1999. Does growth hormone therapy in conjunction with resistance exercise increase muscle force production and muscle mass in men and women aged 60 years or older? Phys Ther, 79:76-82.

Zigmond AS, Snaith RP. 1983. The hospital anxiety and depression scale. Acta Psychiatr Scand, 67:361-70. 
